\title{
7. The Travels and Poems of Matsuo Bashô
}

Lars Vargö

\section{Abstract}

This chapter looks at the iconic $\mathrm{I} 7^{\text {th }}$ century Japanese poet Matsuo Bashô, who is known as the originator of haiku and is most famous for his travel-account Oku no bosomichi, 'The Narrow Road to the Interior'. This account contains many references to Buddhist temples and legends, since the purpose of the trip was not only to "be one with nature" and write poetry, but also to visit religious sites. Bashô was a Buddhist, as well as a Shintôist, a Confucian, and a Daoist. He had studied Zen Buddhism, but had enough worldly attachment to not want to enter a monastery permanently. Through his travel journals, Bashô created an ideal world of itinerant monks and he is often hailed as a role-model for wandering religious poets.

An important part of Japanese poetry has always been renga (連歌), linked poetry written by more than one poet. Already in the $\mathrm{I} 2^{\text {th }}$ century it was a well-developed and regulated form of literary expression. Initially, two poets would write a poem which combined one stanza consisting of 5-7-5 phonetic characters with another consisting of $7-7$ characters. ${ }^{303}$ Later it became popular

303 Modern Japanese has two phonetic alphabets, hiragana and katakana, with 46 characters each, while older Japanese had 48 characters. With the

How to cite this book chapter:

Vargö, L. 202I. The Travels and Poems of Matsuo Bashô. In: Larsson, S. and af Edholm, K. (eds.) Songs on the Road: Wandering Religious Poets in India, Tibet, and Japan. Pp. I27-I40. Stockholm: Stockholm University Press. DOI: https://doi.org/Io.I6993/bbi.g. License: CC-BY 4.0. 
for several poets to create almost endless combinations of stanzas of 5-7-5 and 7-7 sound-characters.

Rules for how the stanzas should be linked became more and more complicated. The first stanza, the bokku (発句), set the tone for the whole poem and introduced the season by which the poem would start. The rules specified when other seasons would come in, and also when stanzas containing references to the moon, flowers, birds, love, et cetera, would be introduced. The poem should always look forward and, although one stanza is always associated with the previous stanza, it should not have anything to do with the one before that. It was important not to look back more than one stanza, with the exception of the last one, the ageku (挙句), which tied the poem together by referring to, or associating with, the theme in the hokku. Usually, the poet who wrote the hokku was the main guest of a poetry-session, and the one writing the second stanza, the wakiku (脇句), was the host. Therefore, the bokku was also a kind of greeting and often referred to something that was connected to the host, for instance the plants in his ${ }^{304}$ garden, the view, the history of the location, specific traditions or events, et cetera.

In the $16^{\text {th }}$ century some poets found the rules stifling and created haikai-no-renga, 'comic/wild/rambunctious renga'. A poet named Matsunaga Teitoku (松永貞徳, I 57I-I654) contributed greatly to the popularization of haikai-no-renga. He created a special school in haikai-poetry, the Teimon school. Another important haikaipoet was Nishiyama Sôin (西山宗因, I605-1682), who thought

exception of the five vowels and one singular consonant (the final $n$ ), all characters are pronounced by combining one consonant and one vowel. Thus, in poetry the characters are often referred to as onji, 'sound characters', or jion, 'character sounds'. While a syllable can contain several letters and a Japanese phonetic character has two letters in Romanization, it is written with only one written character. For instance, the name of the Swedish capital, Stockholm, consists of two closed syllables in Swedish or English, Stock and holm. In Japanese it is written ストックホルム, su-to-k-ku-ho$r u-m u$, containing seven phonetic characters. The grammatical structures of Japanese and Chinese are very different from each other; in the earliest forms of written Japanese, Chinese characters were also used as phonetic characters, which were mixed with other Chinese characters used for their meaning only, making texts extremely difficult to read. Today, Chinese characters and phonetic characters are still used in combination.

304 The poets were almost always men. 
that the Teimon school had got caught in stifling rules and was too concerned with what was right and wrong. Nishiyama argued for more freedom and introduced techniques like honkadori (本歌取り), associations to already well-known classical poems. $\mathrm{He}$ and his followers formed the Danrin school.

Then came Matsuo Bashô (松尾芭蕉, I644-I694), Japan's most well-known poet, often referred to as the originator of haiku. His poetry was the source of yet another school within the haikai tradition, the Shôfû. Bashô was not a stranger to the use of humour in his poetry, but he also stressed the need to stay away from what was too vulgar and instead underlined the necessity of creating refined and elegant poetry. He also limited the number of stanzas to 36, a format he called kasen (歌仙), an abbreviation for sanjûrokkasen (三十六歌仙), 'the 36 hermit-poets', which was a term introduced by the court-bureaucrat and poet Fujiwara no Kintô (藤原公任, 966-IO4I) for the most outstanding poets of his time. Bashô became a hokku-master and famous already in his lifetime. ${ }^{305} \mathrm{He}$ was constantly invited to poetry-sessions and had followers all over the country. However, Bashô was also a skillful writer of prose and his kikô (紀行), travel journals, and haibun (俳文), essays mixed with poetry, are as appreciated as his hokku. Bashô sometimes tired of the secular world and went on long journeys by foot and on horseback to find inspiration, pray at temples, and visit famous places. The wandering in itself served as a kind of cleansing of his spirit and he seemed to yearn for religious experiences, walking through the country as a pilgrim.

Bashô was born not far away from Kyôto, in a village called Ueno, in the ancient province of Iga, today's Mie prefecture. His family was not poor, but not particularly well-off either. His father had samurai status, but of lower rank, which forced him to also work as a farmer. As a samurai he had the privilege of having a surname. Not much is known about his mother, but on a few occasions he fondly wrote poems about her. He had one brother and four sisters. When Bashô was eighteen he began to work as

305 His bokku is often called haiku and the only difference is that while a bokku was always followed by other stanzas, the haiku stands alone. The term haiku was coined by the poet Masaoka Shiki (正岡子規, I867-I902), who argued that a haiku should free itself from linked poetry and be a poetic category of its own. 
an assistant to Tôdô Yoshitada (東堂良忠, I642-I666), an aristocrat and relative to the local lord. Yoshitada was only two years older than Bashô and they became close friends. Together they developed a strong interest in haikai-poetry. After only a few years together, Yoshitada suddenly died in I666. His younger brother took his position as head of the clan and even married Yoshitada's widow. For Bashô this was a great shock and he decided that it was better to leave his village than serving someone whom he did not respect as much. To leave his village meant that he also left the expectations his family had for him and he had to give up his samurai status. There are speculations about Bashô himself having had an affair with Yoshitada's wife and that that was the real reason for his departure; true or not, Bashô would later return several times to his village for short periods.

It is not clear where Bashô immediately went after leaving Ueno, but he probably chose Kyôto, where he later spent a lot of time and became good friend with many poets and cultural personalities. Bashô continued to study haikai-poetry and several of his hokku were selected for publication in various anthologies. In 1672 he took the initiative to edit an anthology himself and managed to collect poems from some 30 poets. I 672 was also the year he left for Edo, which was not only the place where the shôgun resided, but also a city that had begun to compete with Kyôto and Ôsaka as the intellectual and cultural centre of Japan. Bashô received more and more assignments as judge in various haikai-competitions and in $\mathrm{I} 68 \mathrm{O}$ a collection called Tôsei montei dokugin nijikkasen (桃青門弟独吟二十歌仙), '20 independent kasen by Tôsei's disciples', was published - Tôsei (桃青) being the pseudonym used by Bashô at the time. Bashô was now so popular that his disciples built a house for him by the banks of the river Sumida. In the garden they planted a Japanese banana-plant, a bashô, which does not produce bananas, but has large, brittle leaves that easily break if there is a strong wind. He liked the plant so much that he changed his pseudonym to Bashô.

In I684 Bashô undertook his first long journey, which was documented in Nozarashi kikô (野ざらし紀行), 'A weather-beaten journey', published in 1687 . He was accompanied by one of his disciples, Kasuya Chiri (粕屋千里, I648-I7I6) and the journey included a visit to his home-village, where his elder brother 
showed him a tress belonging to his mother who had died one year earlier. Bashô wrote:

I arrived at my home-village during the ninth month. The grass was covered by frost and no traces (of her) were left. Everything had changed. My elder brother, with his white hair on the sides and wrinkles around his eyebrows, could only point out that we were still alive. Then he opened a memory-sack and said: 'Pay respect to your mother's white hair!' [...] We cried.

Bashô added:

If I took it in my hand

it would disappear in my warm tears

autumn frost

Te ni toraba kien namida zo atsuki aki no shimo 306

Bashô was a sensitive poet whose values were firmly founded in Buddhist, Confucian, and Daoist thought. Bashô, although having seriously studied Zen, was never a monk belonging to a monastery, but he often dressed as priest and often stayed at temples and shrines. His great knowledge about, and interest in, the classical Nô theatre could also be seen as a reconfirmation of his religious beliefs. In Nô plays the story often centres around wandering priests and their encounters with spirits and demons. Nô did not have a clear educational purpose, but the moral in the plays had obvious Buddhist undertones.

Bashô, like many Japanese poets before him, was greatly influenced by classical Chinese poets, not least the well-known Tang dynasty poets Li Bai (李白, 70I-762) and Du Fu (杜甫, 7 I 2-770), whom he admired immensely. In classical Chinese poetry there were certain ideals that were seen as necessary for a poet to embrace. One was the need to downplay one's own importance. Another was the poet's difficulties in agreeing with the perceived vulgarities of the societies in which the poets lived. And a third was the readiness to leave society whenever the poet felt it was necessary and wander around, seeking contact with masters of poetry and/or asceticism. These ideals were clearly a factor behind

306 Sugiura \& Miyamoto \& Ogino I979:38. 
the many travels on foot through Japan that Bashô undertook. Nozarashi kikô begins with the statement:

I began a journey of $1000 \mathrm{ri},{ }^{307}$ without any provisions. I held on to the staff of an ancient, who is said to have entered nothingness under the midnight-moon. It was the eighth month of the first year of the Jôkyô reign ${ }^{308}$ as I left my dilapidated hut by the river. The sound of the wind was oddly cold. ${ }^{309}$

The description says a lot about the ideals that Bashô honoured. The first poem of the journal is this one:

Weather-beaten

the wind pierces my body

and soul

Nozarashi wo kokoro ni kaze no shimu mi kana ${ }^{\text {10 }}$

It is followed by:

After ten autumns

it is rather Edo

which is my domicile

Aki totose kaette edo wo sasu kokyô $\hat{o}^{31}$

Bashô had actually lived in Edo for 13 years when he departed on this journey, but here he alludes to the Chinese poet Jia Dao (賈嶋, 779-843), who in a poem called 'Crossing the river Sang Gan' (渡桑乾) used the expression "10 autumns" as an expression indicating that a long time has passed. ${ }^{312}$

The harsh conditions for certain segments of society became painfully obvious to Bashô as he on this journey encountered an abandoned child, not more than two years old, along the Fuji river. The child was weeping in such a way that Bashô was convinced that his parents had left him in this "floating world", as treacherous as the rapids. The child seemed like a bush-clover

\footnotetext{
307 I $r i$ (里) is 2,44 miles. “I000" can here be read as "very long”.

308 I $684 \mathrm{CE}$.

309 Sugiura \& Miyamoto \& Ogino I979:36.

310 Sugiura \& Miyamoto \& Ogino 1979.

3 11 Sugiura \& Miyamoto \& Ogino I 979.

${ }^{12}$ Vargö 20I8:I32.
} 
in the autumn-wind and Bashô threw him some food as he went on. The poem which followed is one of Bashô's most famous:

You who listen to monkeys

what about an abandoned child

in the autumn-wind?

Saru wo kiku bito sutego ni aki no kaze ika ni ${ }^{\text {13 }}$

The cries of the monkeys in combination with the autumn-wind was often used in Chinese poetry to create an atmosphere of melancholy.

As Bashô continued to describe his journey, he referred to the Chinese poet $\mathrm{Du} \mathrm{Mu}$ (杜牧, 803-853), saying:

The moon could only be seen vaguely and at the base of the mountains it was still dark. I let my whip hanging and rode several $r i$ on my horse before the rooster called. I thought of Du Mu's poem 'Early Departure' when suddenly my thoughts were scattered as we arrived at Sayo no Nakayama. ${ }^{314}$

Du Mu had written in his poem:

I keep my whip hanging and trust the way my horse walks

for several $l i$ no rooster can be heard

we move through a grove

still half dreaming

when the leaves suddenly fall over me $\mathrm{e}^{315}$

What then follows is a good description of how Bashô travelled and of his relationship to the religious world. He arrived at a Shintô shrine to worship and noted:

I wear no sword at my belt, I carry an alms-bag hanging over my neck, and I hold a rosary with I 8 beads in my hand. I look like a priest and my head is shaven, but I am a layman. Although I am not a priest, those with shaven heads are treated as Buddhists and are not allowed to enter the shrine. ${ }^{316}$

\footnotetext{
313 Sugiura \& Miyamoto \& Ogino I979:36.

${ }^{14}$ Vargö 20I 8:135.

${ }_{315} l i$ is the same as $r i$ in Japanese.

${ }^{316}$ Sugiura \& Miyamoto \& Ogino I979:37-38.
} 
Bashô was a Buddhist, but he was also a Shintôist, a Confucian, and a Daoist. He had studied Zen, but had enough attachments to this world to make him not want to enter a monastery, apart from short visits. He believed in anything and everything, treated religions with utmost respect, and yet he harbored enough doubts about the religious world to want to maintain his analytical freedom. He was primarily a poet, attracted to the ideal of classical poets, but he also enjoyed the life of a vagabond.

\section{II}

Later in his journal, Bashô composed a poem which shows his fondness for the daily life of local people and the poetic associations they give. He arrived at a scene where peasants were cleaning rice by using a watayumi, 'cotton bow', a bow which has a tendon attached to it. The sound created when someone hits the rice-covered ground with the cotton bow reminded Bashô of the sound of the biwa-lute:

\section{A watayumi \\ the soothing sound of a biwa \\ behind the bamboo \\ Watayumi ya biwa ni nagusamu take no ok ${ }^{317}$}

Bashô and Kasuya Chiri then continued their journey on foot to the Buddhist temple Futagamiyama Taima, where there is an enormous pine-tree in the garden. The tree is probably over rooo years old and has grown so large that an ox can hide behind it. Bashô was happy that people had not been tempted to cut it down. He wrote that although the tree is not a living creature, "its relationship to Buddha has preserved it from the sin of the axe".$^{318}$ The poem which followed also alluded to Chinese saints, in this case the Chinese philosopher Zhuangzi (荘子, said to have lived $370-287 \mathrm{BCE}$ ), who wrote about a giant tree that could hide a thousand cows.

Monks and morning-glories how many incarnations

\footnotetext{
317 Sugiura \& Miyamoto \& Ogino I979:39.

${ }^{118}$ Sugiura \& Miyamoto \& Ogino 1979.
} 
at this dharma-pine?

Sô asagao iku shinikaeru nori no matsu ${ }^{319}$

Bashô was later joined by a monk from the Izu province, who had heard that the great bokku-master was wandering in the vicinity:

Now together

we can eat ears of barley

on our wandering

Iza tomo ni ho mugi kurawan kusamakuraj20

While on the road, Bashô was reached by the sad news that Daiten (大顛, I629-I685), the abbot of the well-known Zen temple in Kamakura, Engakuji, had passed away. Daiten was a priest and poet, who often composed linked poetry together with Takarai Kikaku (宝井其角, I66I-I707), one of Bashô's most important disciples. Bashô wrote a letter to Kikaku expressing his sorrow and lamenting the fact that it had taken so long for him to get the news. The apricot-flowers had already bloomed so Bashô prayed for the soul of the abbot in front of some hydrangeas (hortensias) instead, letting the missing apricot-flowers symbolize the deceased:

I miss the apricot-flowers and pray in front of hydrangeas in tears

Ume koite u no hana ogamu namida kana ${ }^{321}$

The first paragraph in one of his next travel-journals, Kashima Kikô (鹿島紀行, I 687), is a good illustration of the conditions under which poets and monks travelled. Bashô was determined to see the moon over the mountains at the Kashima-shrine in autumn and was accompanied by two men: one a masterless samurai, who also wrote poetry, the other an itinerant monk. The monk wore black robes, reminding Bashô of a crow, and a pouch for sacred objects hanging around his neck. In a portable shrine, which the monk carried on his back, there was an image of the Buddha. As

\footnotetext{
319 Sugiura \& Miyamoto \& Ogino I979.

320 Sugiura \& Miyamoto \& Ogino I 979:43. The word kusamakura means 'grass pillow' and is a metaphor for wandering.

32r Sugiura \& Miyamoto \& Ogino I979.
} 
for himself Bashô said he was neither a monk, nor a man of the world. He likened himself to a bat, something in-between a bird and a mouse.

As they continued their pilgrimage they arrived at a place called Fusa, near the Tone river. It was a place where fishermen use to catch salmon. They boarded a boat and crossed the river to Kashima, where the Zen priest, who had been Bashô's teacher, served as abbot in a temple. They were invited to spend the night there. It had been raining during the night, but in the early dawn the sky cleared somewhat and Bashô woke everyone. The light of the moon in combination with the sound of the rain was almost a religious experience, but Bashô was disappointed that he could not see the full moon. Swiftly moving clouds kept interfering with the scene; it looked in fact as if the moon itself was moving quickly:

The moon moves quickly

as the tree-tops keep

holding the rain

Tsuki hayashi kozue wa ame wo mochinagara

In 1687 Bashô also published his Oi no kobumi, 'Notes from my travel-knapsack'. ${ }^{322}$ The first paragraphs sum up Bashô's philosophy quite well:

Among the hundreds of bones and nine openings of the human body there is something, a spirit of mine, which one can temporarily call 'Monk blowing in the wind'. It is thin and can easily be torn to pieces. For long it has been fond of wild verses, which has become a vice for life. Sometimes it has been full of despair and tried to put the verses aside, sometimes it has felt an exaggerated pride of having reached sublime levels. It has always been indecisive and too eager. At one point it tried to calm itself through worldly success, but poetry put an end to that. On another occasion it tried to enlighten itself through scholastic studies, but also at that time wild verses came in-between as an obstacle. In the end it realized that poetry was the only way to continue. Saigyô's waka-poetry,

322 The character oi (笈) was a box made of bamboo carried like a knapsack. It was often used by itinerant priests or wandering monks for their few possessions, not least scriptures, books or notebooks. 
Sôgi's linked verses, Sesshû's painting, Rikyu's tea-ceremony they all have something in common: that which is artfully refined. [...] Those who do not see the flowers are like barbarians. Those who do not leave room for flowers in their hearts are like animals. By leaving barbarism and distancing oneself from the animals one can become part of nature. It was the beginning of the month when the gods were absent. ${ }^{32}$ The skies were unsettled and as for myself, I was an autumn-leaf in the wind, not knowing where to go. ${ }^{324}$

Wanderer
will I call myself
the first winter-rain
Tabibito to waga na yobaren hatsu shigure

A poet, who called himself Chôtarô and followed Bashô a bit on his journey, added the following verse:

And the camellias

will serve as your

lodgings

Mata sazanka wo yadoyado ni shite ${ }^{325}$

Bashô's most famous travel account is also a record of his longest trip on foot: Oku no hosomichi, 'The narrow roads to the inner parts (of the country)'. It was a trip that lasted I 50 days. His travel companion for the main part of the journey was the disciple Sora (曾良, I649-I7I0), who wrote his own diary about the experience. Before leaving they took an emotional farewell of their friends, who had followed them across the river Sumida. It was the $27^{\text {th }}$ of March according to the moon-calendar, and the $16^{\text {th }}$ of May according to the modern one.

Passing spring

the birds cry and fish

have tears in their eyes

Yuku haru ya tori naku uo no me wa namida ${ }^{326}$

\footnotetext{
323 October according to the moon-calendar.

324 Sugiura \& Miyamoto \& Ogino I979:52.

325 Sugiura \& Miyamoto \& Ogino I979.

326 Sugiura \& Miyamoto \& Ogino I979:7 I.
} 
There are many references to Buddhist temples and legends in Oku no hosomichi and the purpose of the trip was not only to "be one with nature" and write poetry, but also to visit famous religious sites. Having wandered a long distance for several days, Bashô and Sora reached the Buddhist temple Risshaku in Yamagata, belonging to the esoteric Tendai sect. The temple is also called Yamadera, 'the mountain temple', as it is situated on the top of a mountain. The many steps leading up to the temple were exhausting to climb and the summer heat was intense. The cicadas were crying loudly and broke the silence.

Stillness,

the cry of the cicadas

penetrates the rock

Shizukasa ya iwa ni shimi-iru semi no koe $e^{327}$

Towards the end of this long journey Bashô was staying overnight at a Zen temple belonging to the Sôtô-sect, Zenshôji. It was customary for guests to sweep the temple-garden as a form of payment before leaving. When Bashô began to use the broom, a couple of monks came running with paper, brush, and ink, asking him to write a poem for them:

Sweeping the garden

before leaving the temple

as willow-leaves fall

Niwa haite idebaya tera ni chiru yanagi ${ }^{328}$

Bashô continued to the temple Tenryûji, also belonging to the Sôtô sect. He knew the abbot there well. This time Bashô was followed on his way to the temple by a person who called himself Hokushi, 'Northern Branch' (北枝). Hokushi also wanted to receive a poem. Bashô tore off a piece of a folding-fan and wrote:

I write something

and tear off a piece of the fan

as memory

Mono kaite ôgi hikisaku nagori kana ${ }^{329}$

\footnotetext{
327 Sugiura \& Miyamoto \& Ogino I979:87.

328 Sugiura \& Miyamoto \& Ogino I979:95.

329 Sugiura \& Miyamoto \& Ogino I 979:96.
} 


\section{III}

Bashô approached the end of this journey, but first arrived at the famous Zen temple Eiheiji, established by the founder of the Sôtô sect, the Zen master Dôgen (道元禅師, I 200-I 253), where he wanted to pray before moving on to Higuchi castle, where he heard the first wild geese of autumn. The moon was exceptionally bright in the evening, when he came to an inn and asked the inn-keeper if it would be as bright the next evening. The innkeeper told him that it was impossible to tell and offered him some sake. Bashô also wanted to take the opportunity to worship at the site of emperor Chûai, ${ }^{330}$ where "the moon-light filtered through pines and white sands spread before the sanctuary like frost". ${ }^{33 \mathrm{I}}$ The inn-keeper told Bashô that a priest called Taa Shônin (他阿上人, I237-I3I9) wanted worshippers to be able to come to the site without problems and therefore cut the grass and brought lots of sand and stones to cover the muddy ground. Taa Shônin was the second abbot at the temple Yugyôji (遊行寺), 'Temple of Pilgrims' - the first one being Ippen Shônin (一遍上人, I 239-I 289), an itinerant priest who founded the Jishû, 'Time sect' (時宗), a branch of the Pure Land sect, Jôdoshû (浄土宗). Inspired by Taa Shônin, priests have continued to bring sand to the site in a yearly ceremony called sunamochi, 'bringing sand'.

The clear moon

over the pilgrims

bringing sand

Tsuki kiyoshi yugyô no moteru suna no ue $33^{32}$

Bashô died relatively young, only 50 years old, and although this was a respected age in his time he could have lived much longer had he taken better care of himself. He died on his way to Ôsaka. Bashô had been invited to attend several poetry-sessions and forced himself to accept the invitations in spite of feeling ill. A few days before the end he wrote the following poem:

This autumn

why do I age this way?

330 仲哀天皇, the $14^{\text {th }}$ emperor of Japan, died 200 CE.

33r Barnhill 2005:75.

332 Sugiura \& Miyamoto \& Ogino I979:97; Barnhill 2005:75-76; Vargö 20I8:364. 
A bird flies into a cloud

Kono aki wa nande toshi yoru kumo ni tori333

Finally, Bashô had to decline an invitation to attend a poetry-session, because of his illness, but from the house where he was resting, he sent a poem, filled with dry humour, to the host. He was lying in bed and wondering what the noise coming from a neighbour was all about:

The autumn is deep

the person next door

what is he up to?

Aki fukaki tonari wa nani wo suru hito $z O^{334}$

Three days before he died Bashô wrote his farewell-poem:

Fallen ill on the journey

my dreams wander around

the withered field

Tabi ni yande yume wa kareno wo kakemeguru 335

Bashô was a wandering poet, religious at times, less religious on other occasions. On his journeys he dressed as a Buddhist priest, partly because he wanted to travel like an itinerant priest, partly because it gave him protection against robbers, since priests were not known for carrying anything valuable. Through his travel-journals Bashô created an ideal world of itinerant monks and is often hailed as a role-model for wandering religious poets. Today one can find large stones with inscriptions of his poems along the routes he took.

\section{References}

Barnhill, David L. 2005. Bashô's Journey: The Literary Prose of Matsuo Bashô. New York: State University of New York Press.

Sugiura \& Miyamoto \& Ogino. 1979 (1959). Bashô bunsh $\hat{u}$. Nihon koten bungaku taikei 46 . Iwanami Shoten.

Vargö, Lars. 20I8. Bashô: Blommornas, fåglarnas och månens poet. Carlsson bokförlag.

333 Vargö 20I 8:576.

334 Vargö 20I 8:578.

335 Vargö 20I 8:578-579. 